\title{
The successful use of mycophenolate mofetil in a patient with active birdshot chorio-retinopathy refractory to azathioprine therapy - Case report
}

\author{
O uso com sucesso de mofetil de micofenolato em um paciente com coriorretinopatia \\ de "birdshot" a tiva refratá ria à terapia com azatioprina-Relatodecaso
}

Raul N. G. Vianna ${ }^{1}$

Nadia Al-Kharusi ${ }^{2}$

Jean Deschênes ${ }^{2}$

\begin{tabular}{|l|}
\hline ABSTRACT \\
\hline Report on the effect of oral mycophenolate mofetil (MMF) on the treatment \\
of a patient with active birdshot chorioretinopathy (BC) refractory to \\
azathioprine (AZA) therapy. A sixty-two-year-old female patient with BC \\
developed cystoid macular edema (CME) and severe retinal vasculitis in \\
both eyes. AZA (2 mg/kg/day) was then initially prescribed in order to \\
control the inflammatory process. As AZA failed to control the intraocular \\
inflammation after one year, it was replaced by MMF $(2 \mathrm{mg} / \mathrm{kg} /$ day), which \\
controlled the inflammatory process and improved the patient's visual \\
acuity. In three years under MMF, no recurrence was observed and her \\
vision remained unchanged. In our patient with active BC refractory to \\
AZA, MMF was effective to decrease the intraocularinflammation, as well \\
as to improve the patient's visual acuity.
\end{tabular}

Keywords: Mycophenolic acid/therapeutic use; Chorioretinitis/drug therapy; Choroid diseases/drug therapy; Retinal vasculitis; Azathioprine/therapeutic use; Case report [Publication type]

\section{INTRODUCTION}

Birdshot chorioretinopathy (BC) is an uncommon form of chronic intraocular inflammation characterized by vitritis and multiple, bilateral, hypopigmented, postequatorial fundus inflammatory lesions ${ }^{(1)}$. Therapy of BC with systemic and periocular steroids is well known, but of variable efficacy and usually many long-term side effects occur $^{(2)}$. For this reason, immunosuppressive therapy has been described as the first line treatment for $\mathrm{BC}^{(3-4)}$.

In this paper we describe a patient with $\mathrm{BC}$ in whom azathioprine (AZA) failed to control the intraocular inflammation. AZA was then replaced by mycophenolate mofetil (MMF), which controlled the inflammatory process and improved the patient's vision. No recurrences were observed while under MMF therapy. In fact, it has been suggested that MMF is a safe and effective immunosuppressive agent in the management of intraocular inflammation in patients with $\mathrm{BC}^{(5)}$.

\section{CASE REPORT}

A 62-year-old white woman was referred to the Uveitis Service, Royal Victoria Hospital, McGill University Health Center, with a 4-week history of floaters, photophobia and decreased vision in both eyes. Her past medical 
history was unremarkable. At the time of initial examination, best-corrected visual acuity was $20 / 70$ in both eyes. The intraocular pressure was $16 \mathrm{mmHg}$ bilaterally, and there were no signs of anterior segment inflammation. The fundoscopic examination revealed +2 vitreous cells, as well as numerous creamy-colored multifocal lesions at the level of the retinal pigment epithelium of both eyes. Moreover, both maculas showed cystoid edema. The optic nerves were normal. Fluorescein angiography confirmed the cystoid macular edema but showed irregular patches of fluorescence, which were not corresponding to those chorioretinal creamy lesions seen on ophthalmoscopy. Further work up included blood tests to rule out other possible causes of multifocal choroiditis. The laboratory results were negative except for HLA- A29, which was positive. The diagnosis of $\mathrm{BC}$ was then confirmed. The patient started oral prednisone $(60 \mathrm{mg}$ /day) supplemented by subtenon injections of $40 \mathrm{mg}$ of triamcinolone in both eyes. However, within one month her visual acuity decreased to 20/100 in both eyes due to cystoid macular edema. Azathioprine ( $2 \mathrm{mg} /$ $\mathrm{kg}$ /day) was then started once a day. Two months later the patient's symptoms improved dramatically in the right eye (RE) and to a lesser extent in the left eye (LE), with visual acuity of 20/25 in RE and 20/60 in LE. Ophthalmoscopy now revealed reduction of cystoid macular edema in RE and persistence of the edema in LE. The same treatment was continued and the follow-up scheduled in four months. After this time visual acuity was 20/25 in RE with resolution of the cystoid macular edema and 20/70 in LE with persistence of the cystoid macular edema. A subtenon injection of triamcinolone $40 \mathrm{mg}$ was administered to LE. Four months later the patient reported marked improvement in both eyes with documented visual acuity of 20/20 in RE and 20/30 in LE. Ophthalmoscopic examination showed resolved edema in both eyes. In the subsequent follow-up at four months the patient complained of fluctuation in LE vision with documented visual acuity of 20/60 in RE and 20/80 in LE (Figure 1). Ophthalmoscopic examination showed the recurrence of cystoid macula edema in LE. The clinical evidence of disease progression while on AZA warranted a change in the management. AZA was then replaced by MMF (1 g/2X/day). Within two months the patient presented with a visual acuity of 20/20 in RE and 20/30 in LE. After one year under MMF treatment, the dose was decreased to $500 \mathrm{mg} / 2 \mathrm{X} / \mathrm{day}$. Since she started MMF therapy, no recurrence of the cystoid macula edema was detected over a threeyear period (Figure 2). The patient also did not report any systemic side effects related to MMF.

\section{DISCUSSION}

$\mathrm{BC}$ is a rare clinical entity characterized by scattered cream-colored or whitish depigmented areas in the fundus, cystoid macular edema, papillitis and chronic vitritis, but with minimal or no anterior segment involvement ${ }^{(1)}$. The most com-

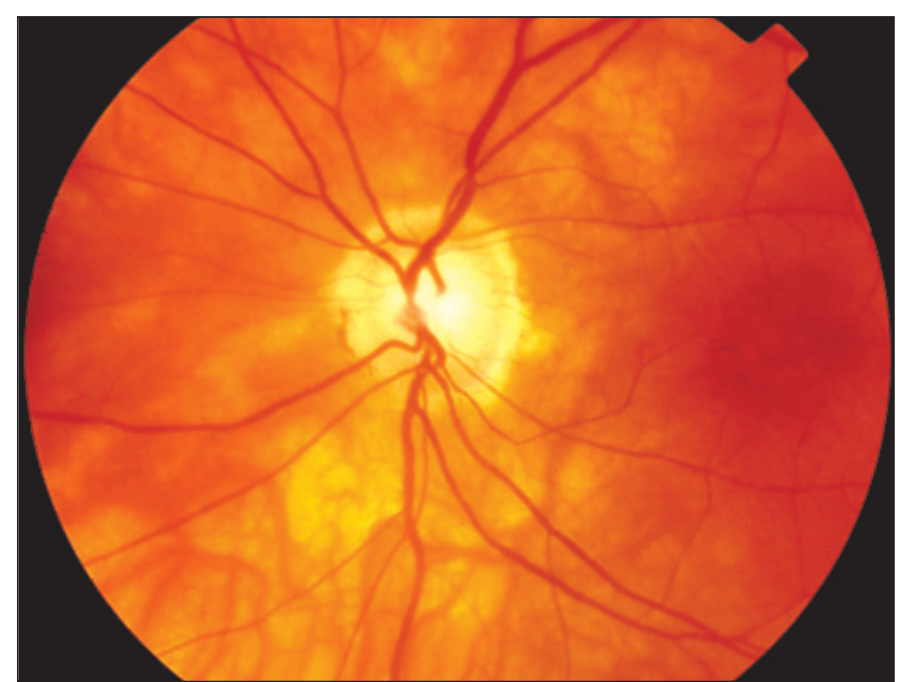

Figure 1 - Color photograph of the left fundus showing the creamcolored patch lesions located throughout the chorioretina and around the optic disc. There is cystoid macular edema and the visual acuity is 20/80. At this time, the patient was under AZA therapy

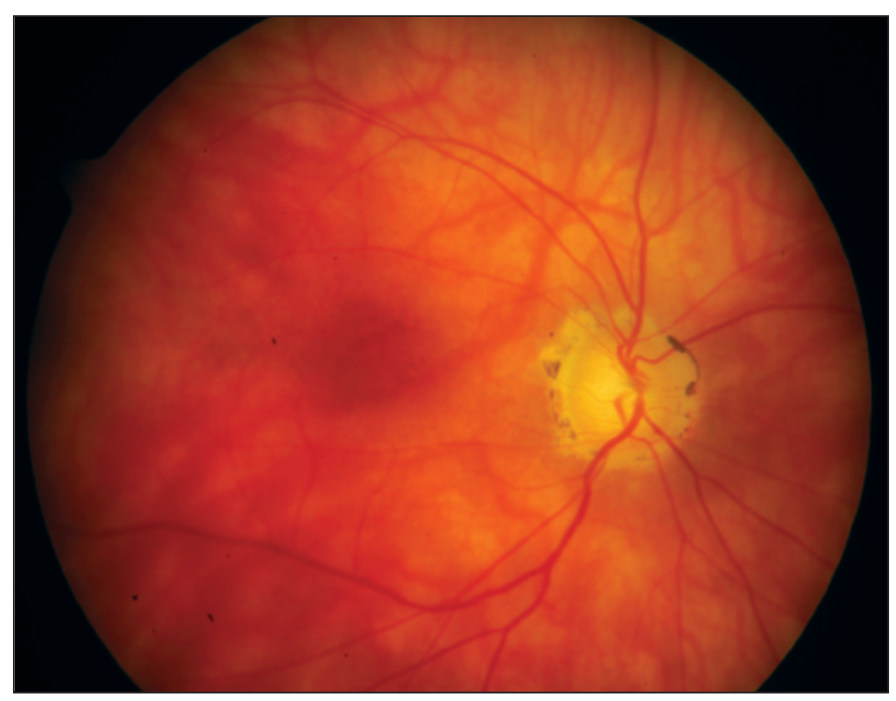

Figure 2 - Color photograph of the left fundus three years after treatment with MMF revealing cicatricial scars surrounding the optic disc. The visual acuity is now 20/30 and the cystoid macular edema has decreased

mon complication of $\mathrm{BC}$ is chronic macular edema, occurring in over $50 \%$ of cases, and macular edema is the most frequent cause of reduced vision ${ }^{(1)}$. The cause of $\mathrm{BC}$ is unknown, but its strong association with HLA-A29 suggests that it may be an autoimmune disease ${ }^{(6)}$.

The mainstay of treatment of $\mathrm{BC}$ patients has been the use of either periocular or systemic corticosteroids. However, the long-term use of systemic corticosteroids at the dose required to suppress the choroidal inflammation is likely to produce severe side effects, therefore, an immunosuppressive agent is warranted. In fact, some recent papers suggest that immunosuppressive therapy would be the best option to manage BC patients $^{(3-5)}$. 
Uncontrolled case series have suggested that cyclosporine may be effective for BC. Vitale et al found that vitritis and visual acuity were controlled in approximately $85 \%$ of the patients treated with cyclosporine ${ }^{(4)}$. In contrast, in the same study, only $46 \%$ of the BC patients treated with corticosteroid therapy alone experienced an improvement in visual acuity during the follow-up period. However, due to cyclosporine toxicity, other less toxic immunosuppressive therapy options should be evaluated.

MMF is a selective inhibitor of inosine monophosphate dehydrogenase that interferes with guanosine nucleotide synthesis. MMF acts preventing lymphocyte proliferation, suppresses antibody synthesis, interferes with cellular adhesion to vascular endothelium, and decreases recruitment of leukocytes to sites of inflammation ${ }^{(2)}$. After oral administration, MMF is absorbed within 30 minutes and is converted in the liver to its metabolically active form. Coadministration with antiacids results in reduction of absorption ${ }^{(2)}$.

MMF has been used at a dose of 1 to $3 \mathrm{~g}$ daily for prevention of solid organ transplant rejection. It has been suggested that MMF is an effective agent in the treatment of ocular inflammatory diseases, particularly when it is used in combination with corticosteroids, and in some cases, with cyclosporine $^{(2)}$. Indeed, Baltatzis et al reported 54 patients with chronic ocular inflammatory disorders (including seven patients with $\mathrm{BC}$ ) in whom the inflammatory process was controlled in $75 \%$ of cases ${ }^{(5)}$. In this study, the control of ocular inflammation with MMF as monotherapy was achieved in $35(65 \%)$ patients, and a steroid-sparing effect was achieved in $29(54 \%)$ patients. In the mentioned paper, there was neither long-term morbidity nor mortality due to MMF. Lau et al assessed the long-term efficacy of MMF in the control of severe intraocular inflammation in 14 patients (no BC case) ${ }^{(7)}$. Within a mean of 33 months, 10 patients remained under control; the inflammation was unchanged in three and deteriorated in one patient.

In our case the inflammation was refractory to AZA. MMF was then started and controlled the inflammatory process during a three-year follow up. Gastrointestinal complaints, like pain, nausea, vomiting, and diarrhea, which can be observed in approximately $30 \%$ of the patients under MMF, were not seen in our patient. More severe complications associated with the use of this agent (leukopenia and lymphoma) in patients taking doses over $3 \mathrm{~g} / \mathrm{day}^{(2)}$ have been reported. However, doses of 1 to $3 \mathrm{~g}$ /day, as previously mentioned, are considered to be safe. In fact, at this range ( $\mathrm{g} /$ day and, later, $1 \mathrm{~g} /$ day) the inflammation in our patient was successfully controlled and she tolerated well the medication during a three-year period. It is important to point out that patients under MMF should be monitored with complete blood count and liver function every two months.

Despite the good visual outcome observed in the presented case, studies with a large series of patients are warranted to reach definitive conclusions about the efficacy of MMF for BC.

\section{RESUMO}

Relato da eficácia da terapia com micofenolato mofetil (MMF) no tratamento de paciente com coriorretinopatia do tipo "birdshot" (CB), no qual o processo inflamatório intra-ocular foi refratário ao uso de azatioprina (AZA) apos um ano de terapia. Paciente de 62 anos de idade e com CB desenvolveu edema macular cistóide e vasculite retiniana em ambos os olhos. No intuito de controlar a inflamação intra-ocular, a terapia com azatioprina oral $(2 \mathrm{mg} / \mathrm{kg})$ foi iniciada. Como a terapia com AZA não se mostrou eficaz a médio prazo, esse medicamento foi substituido pelo MMF, o qual controlou controlou o processo inflamatório com conseqüente melhora da acuidade visual do paciente. Após 3 anos de tratamento com MMF, nenhuma recorrência foi observada. Neste paciente com $\mathrm{CB}$ refratária ao tratamento com AZA, o MMF foi eficaz em debelar a inflamação intra-ocular.

Descritores: Ácido micofenólico/uso terapêutico; Coriorretinite/quimioterapia; Doenças da coróide/quimioterapia; Vasculite retiniana; Azatioprina/uso terapêutico; Relato de caso [Tipo de publicação]

\section{REFERENCES}

1. Priem HA, Oosterhuis JA. Birdshot chorioretinopathy: clinical characteristics and evolution. Br J Ophthalmol. 1988;72(9):646-59.

2. Jabs DA, Rosenbaum JT, Foster CS, Holland GN, Jaffe GJ, Louie JE et al. Guidelines for the use of immunosuppressive drugs in patients with ocular inflammatory disorders: recommendations of an expert panel. Am J Ophthalmol. 2000;130(4):492-513. Review.

3. Le Hoang P, Girard B, Deray G, Le Minh H, De Kozak Y, Thillaye B et al. Cyclosporine in the treatment of birdshot retinochoroidopathy. Transplant Proc. 1988;20(3 Suppl 4):128-30.

4. Vitale AT, Rodriguez A, Foster CS. Low-dose cyclosporine therapy in the treatment of birdshot retinochoroidopathy. Ophthalmology. 1994;101(5):822-31.

5. Baltatzis S, Tufail F, Yu EN, Vredeveld BA, Foster CS. Mycophenolate mofetil as an immunomodulatory agent in the treatment of chronic ocular inflammatory disorders. Ophthalmology. 2003;110(5):1061-5.

6. Priem HA, Kijlstra A, Noens L, Baarsma GS, De Laey JJ, Oosterhuis JA. HLA typing in birdshot chorioretinopathy. Am J Ophthalmol. 1988;105(2):182-5.

7. Lau CH, Comer M, Lightman S. Long-term efficacy of mycophenolate mofetil in the control of severe intraocular inflammation. Clin Experiment Ophthalmol. 2003;31(6):487-91. 